NOTES

\title{
An inexpensive portable platform for wildlife observation in the forest canopy
}

\author{
Una plataforma económica y portátil para la observación de fauna silvestre en el dosel del bosque
}

\author{
Maurice Peña-Foxon a*, Iván A Díaz ${ }^{\text {a }}$ \\ *Corresponding author: ${ }^{a}$ Universidad Austral de Chile, Facultad de Ciencias Forestales y Recursos Naturales, Laboratorio de \\ Biodiversidad y Ecología del Dosel, Casilla 567, Valdivia, Chile, maurice.pena@gmail.com
}

\begin{abstract}
SUMMARY
Since the 1980s, many canopy access methods have been developed, ranging from light, small and low-cost techniques to large, heavy and expensive ones. Nevertheless, few "low-tech" methods offer comfort and security during wildlife observation in the canopy. Herein, we describe a light portable swing that is quick and easy to install. This swing provides excellent comfort and security conditions and has been used during several hours of bird surveys in the Chilean temperate rainforest canopy.
\end{abstract}

Key words: swing, canopy access, tree climbing, birdwatching

\section{RESUMEN}

Desde los años 1980, se han desarrollado varias técnicas de acceso al dosel del bosque, algunas basadas en elementos livianos, compactos y de bajo costo hasta otras basadas en una gran infraestructura y alto costo. Sin embargo, pocos métodos de "tecnología sencilla” ofrecen confort y seguridad durante las observaciones de fauna desde el dosel. En este trabajo, describimos un columpio portátil, liviano, que se puede instalar rápida y fácilmente. Este columpio provee gran comodidad y seguridad, y ha sido utilizado para muestreos de aves de varias horas de duración en el dosel del bosque templado de Chile.

Palabras clave: columpio, acceso al dosel, escalada de arboles, avistamiento de aves.

\section{INTRODUCTION}

Canopy access techniques have significantly improved over the last three decades. Towers, cranes, walkways or aircraft, qualified as « high-tech» methods (Barker and Sutton 1997, Mitchell et al. 2002, Lowman and Rinker 2004), have been adapted or built for forest canopy studies. Although they offer more comfortable and rapid access to the highest branches in the canopy, along with more freedom of movement, than rope climbing does, they are expensive, require skilled operating personnel and take, at least, from several days to several months to install. Despite their functional advantages, their great volume and size may significantly alter animal behavior in field studies compared to "natural" conditions (Nadkarni 1988, Bouricius et al. 2002).

In contrast, "low-tech" methods (Barker and Sutton 1997), such as ropes, ladders, boles, spiked-leg irons or tree-gripers have minimum costs and are portable and lighter than the structures described above. In fact, field methods using rope climbing techniques, such as SRT, are still the most popular among researchers, after groundbased techniques (Laman 1995, Barker and Pinard 2001).

When collecting field data on animal behavior in the forest canopy, it is ideal to climb up the tree, as close to the height of the subject under study as possible, avoiding the blocking effect of the evergreen foliage and branches (Perry 1978, Munn and Loiselle 1995). Unfortunately, "low-tech" methods do not always sufficiently provide for the observer's comfort, which is not a negligible issue when conducting systematic observations for several hours in the forest canopy (Loiselle 1988, Munn 1991, Lowman and Bouricius 1995). Nadkarni (1988) described a collapsible cot, which can be easily and quickly hung from a limb. In this article, we describe a portable swing that, contrary to Nadkarni's cot can be easily handmade and has some improvements in terms of comfort, security and mobility. It has been used for extended time periods in birdwatching surveys in the canopy of an evergreen in southern Chile (Díaz 2009) together with access rope techniques (Perry 1978, Dial and Tobin 1994, Laman 1995).

\section{METHODS}

Unlike common swings, this swing hangs from one point instead of two. It is made of two wooden boards suspended with ropes and hung from a carabiner. The bottom 
board (63 x $25 \mathrm{~cm}, 25 \mathrm{~mm}$ thick) (figure 1A) is the seat, whereas the top one $(56 \times 12 \mathrm{~cm})$ (figure 1B) keeps ropes parallel without disturbing the observer's movements. The distance between the two boards is approximately one meter. Perforations of $10 \mathrm{~mm}$ diameters are made in the four corners of the top board. The distance between the two pairs of holes should be $50 \mathrm{~cm}$. Identical perforations are made in the bottom board. About $10 \mathrm{~cm}$ should remain on one side of the bottom board.

A $5.5 \mathrm{~m}$ long, $8 \mathrm{~mm}$ thick rope runs first through one hole of the top board and then through the hole in the same corner of the seating board. The rope then goes up through the opposite hole in the same end of the bottom board and finally through the corresponding hole of the top board. Before and after every hole, an overhand knot should be made, taking care to separate the two boards by about one meter. An overhand loop is then made at both ends of the rope. The same operation must then be performed at the opposite end of the boards using a second rope $5.5 \mathrm{~m}$ long. The four overhand loops are then joined with a carabiner (figure 1C).

Some additional features were added in order to upgrade the swing's efficiency, comfort and safety. 1) Two 200 $\mathrm{cm}$ long strings (nylon throwline for example) (figure 1D) allow the observer to easily and quickly direct the swing in a $360^{\circ}$ circle. To make these strings operational, a $3 \mathrm{~cm}$ long staple is nailed in the middle of the breadth at each extremity of the inferior side of the top board. One end of one of the $200 \mathrm{~cm}$ long strings is tied to the left vertical front rope of the swing with a 4/2 Blake's hitch (figure $1 \mathrm{E})$. The other end of the string runs through the staple just over this knot, crossing the front side of the swing and then going through the other staple before finally being tied to the right front rope with another 4/2 Blake's hitch (figure 1 , insert 1a). An overhand loop (figure $1 \mathrm{~F}$ ) is made in the middle of this string. The second $200 \mathrm{~cm}$ long string does the same, but this string joins both back vertical ropes and runs across the backside of the swing, although still going through the same staples. Each string allows the observer to move $180^{\circ}$ (see below). 2) A $35 \mathrm{~cm}$ long cleat (25 x $25 \mathrm{~mm}$ ) (figure 1, G) acts as a foot rest in order to support the observer's leg's weight and reduce stress. This piece is hung by a thin string to the same carabiner which holds the swing. 3) A ring or a strong hook (figure $1 \mathrm{H}$ ) is also fixed under the seat, between the observer's legs, to hang a bag or backpack containing light instruments, clothes and food. 4) A square wooden piece $(10 \times 10 \mathrm{~cm}, 15 \mathrm{~mm}$ thick $)$ with an $8 \mathrm{~cm}$ diameter hole is screwed on the 10 extra centimeters of the bottom board and acts as a cup holder (figure 1I). 5) A suitable piece of fabric or a basic net can be installed between the two back ropes of the swing as a back rest.

\section{RESULTS}

In order to install the swing, the climber must first look up into the tree for an intersection of two limbs or for one

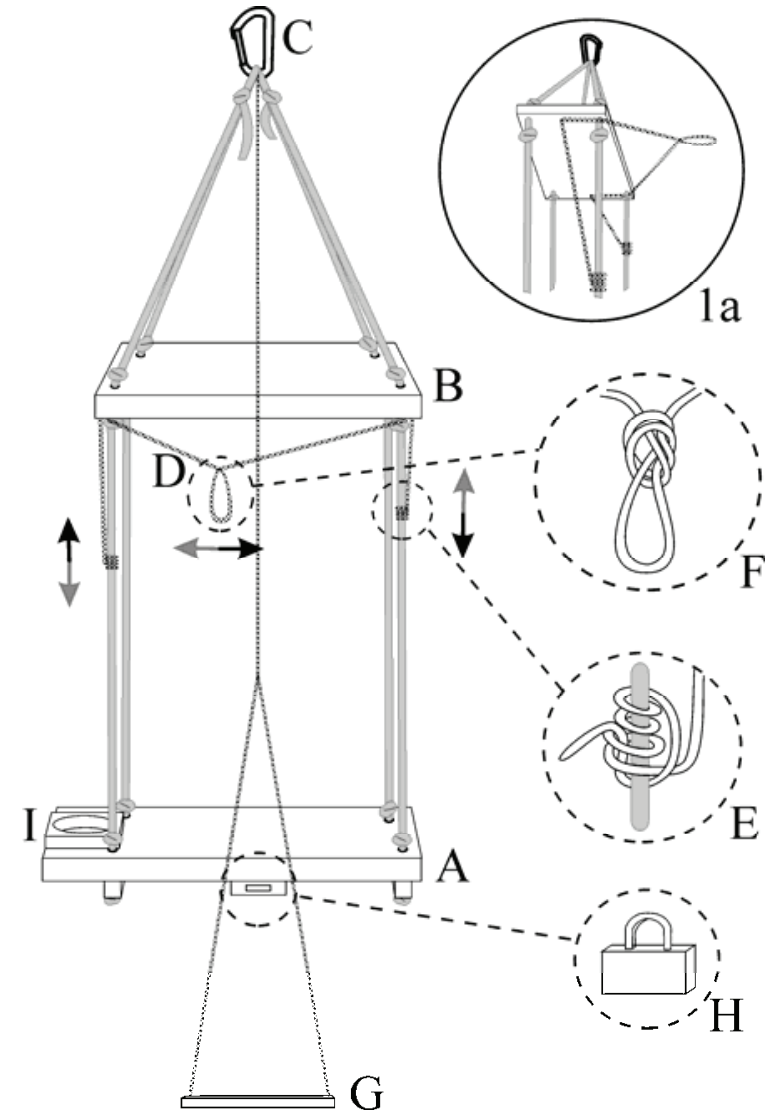

Figure 1. Front view of the portable platform. A) $63 \times 25 \mathrm{~cm}$ bottom board - Seat B) 56 x $12 \mathrm{~cm}$ top board C) Carabiner D) " $180^{\circ}$ rotation string" (for clarity, only one has been drawn) E) 4/2 Blake's hitch (drawn untied) F) Overhand loop (drawn untied) G) Foot rest H) Backpack hanging hook I) Cup holder. Insert 1a: Lateral view and zoom of top board to show one of the two " $180^{\circ}$ rotation string" pathway. Arrows show the directions of the movements of the overhand loop.

Vista frontal de la plataforma portátil. A) Tabla inferior de 63 x $25 \mathrm{~cm} \mathrm{B)} \mathrm{Tabla} \mathrm{superior} \mathrm{de} 56$ x $12 \mathrm{~cm} \mathrm{C)} \mathrm{Mosquetón} \mathrm{D)} \mathrm{Cuerda} \mathrm{para}$ girar el columpio en $180^{\circ}$ con nudo gaza superior (solo una cuerda se muestra) E) Nudo Blake 4/2 (dibujado suelto) F) Gaza superior (dibujado suelto) G) Soporte para los pies H) Gancho auxiliar I) Posa-vaso. Inserto 1a: Vista lateral de la tabla superior que muestra una de las dos cuerdas que permite moverse en $180^{\circ}$. Las flechas indican el sentido de los movimientos de las cuerdas.

horizontal limb, alive and able to support the climber's weight. To hold the swing, a four-meter (or more) long polyester rope, $10 \mathrm{~mm}$ in diameter, with a figure eight knot on a bight at one end must be thrown over the chosen limb. This limb can even be the same on which we are suspended, but in that case we must take care that this rope does not run over the climbing rope. A second figure eight knot on a bight is made at the point where, once the swing is hung to those two knots with the carabiner (figure 1C), the observer is seated at the desire height. Alternatively, instead of this second knot, the free end of the rope can be tied 
to the main trunk. Now the climber must simply descend until he/she is comfortably seated on the swing. The climber must remain fastened to the climbing rope at all times.

To direct the swing and minimize the back and forth wind effect, a second anchorage is made using a thin string (figure 2). Before the climber sits on the swing, he/she must run the string around the trunk or the nearest branch, preferably at the same level of the top board for best results, and tie one end to the rest of the string with a 5/3 Blake's hitch (figure 2A). Then, a figure eight knot on a bight (figure 2B) is made a few centimeters from the Blake's hitch and is connected by a carabiner (figure $2 \mathrm{C}$ ) to the overhand loop (figure 2D) of one of the " $180^{\circ}$ rotation strings" (figure 1D). These two knots (figure 2A and B) should be within the climber's reach once he/she is seated. The observer must play with all three Blake's hitches to give the adequate tension to the strings. To direct the swing (figure $2 \mathrm{E}$ ) towards the observation target, the observer has to simultaneously move one of the $4 / 2$ Blake's hitches on the swing's vertical rope (figure 1E) up with one hand, while moving the other down with the other hand. This allows the observer to move the overhand loop to the right or the left (figure 1F and figure 2D), and so rotate the swing (see arrows on figure 1). To see behind him/her, the observer simply has to change the carabiner to the overhand loop of the other " $180^{\circ}$ rotation string". This way the observer can observe in a $360^{\circ}$ circle without having to twist.

For security, before leaving the swing, the climber must check that all devices and knots connecting his/her harness to the climbing rope are still secure. To leave the swing smoothly and safely, the climber needs to climb up the rope a little bit instead of "throwing" him or herself out of the swing.

\section{DISCUSSION AND CONCLUSIONS}

Fixed or portable platforms have been used in several studies to do observations in the forest canopy (Bates 1944, Perry and Williams 1981, Loiselle 1988, Nadkarni and Matelson 1989, Lowman and Bouricius 1995). For fixed platforms, the difficulty is to find the combination of 2 , 3 or more limbs at the ideal height to hold the structure. It is time consuming both to find the appropriate limbs and, later, to build the platform. The advantage of the swing presented here is that it hangs from only one point so it can be easily and quickly installed on any safe limb close to the climbing rope, thus, greatly increasing the chances of finding good placement. The collapsible cot described by Nadkarni (1988) or the Bosun's chair presents similar functions. However, the swing presented here has several advantages. It is smaller, permitting it to swivel more easily while hanging (63 cm length compared to $180 \mathrm{~cm}$ for the cot), the top board keeps ropes away from the observer and the two " $180^{\circ}$ rotation strings" allow the observer to quickly and easily change directions and maintain

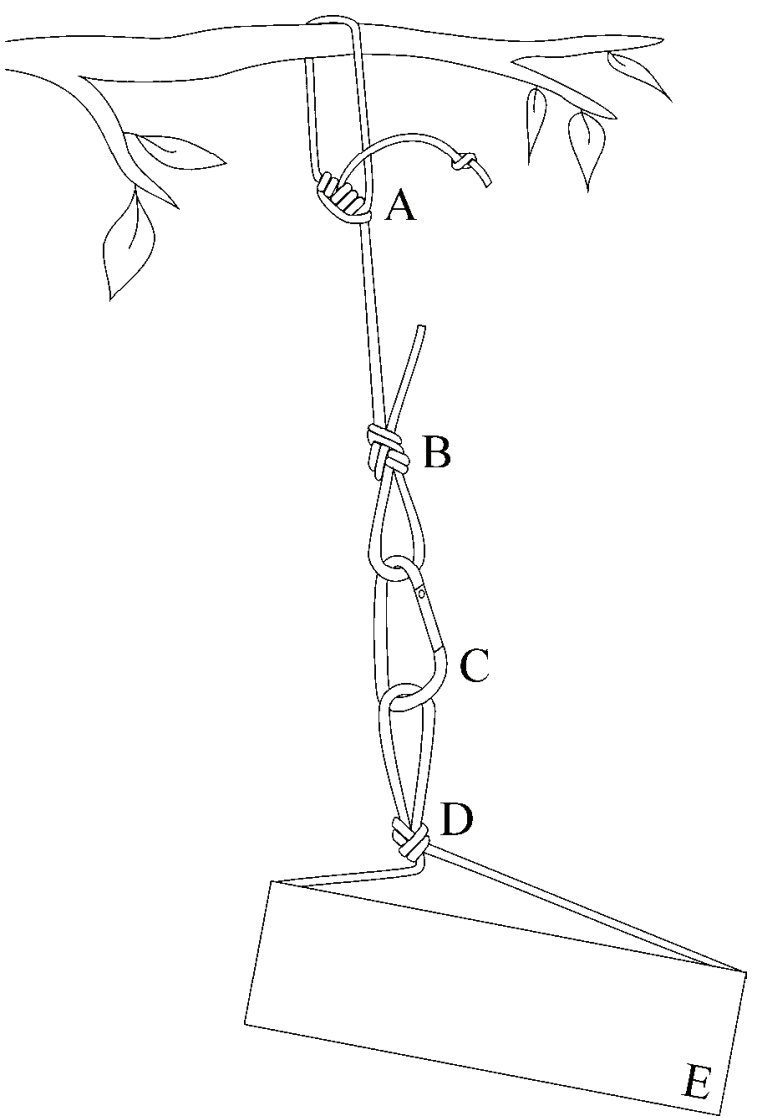

Figure 2. Aerial view of the swing's upper board connected to a branch by a string. A) 5/3 Blake's hitch B) Figure eight knot on a bight C) Carabiner D) Overhand loop of the " $180^{\circ}$ rotation string” E) upper side of the top board of the swing. Swing, knots and carabiner are oversized when contrasted to the top board. For clarity, ropes and carabiner of the swing were not drawn.

Vista de la tabla superior conectada a una rama por una cuerda delgada. A) Nudo Blake 5/3 B) Nudo figura ocho C) Mosquetón D) Gaza superior para moverse en $180^{\circ}$ E) Tabla superior del columpio. La cuerda, los nudos y el mosquetón están sobredimensionados. Las cuerdas y el mosquetón que sostienen el columpio no fueron dibujadas.

a new viewpoint of observation. All of these features are particularly useful when observing wildlife in the canopy because they prevent difficult, uncomfortable and unsecure positions otherwise inevitable with less mobile platforms.

In addition, its light weight (approximately $4 \mathrm{~kg}$ ) and small size make it easy to carry into the forest. It can be easily built out of materials found in any hardware store at a very low cost. Neither the ropes used for the swing nor those to hang the swing need to be special climbing ropes, which are quite expensive. However, these ropes should preferably be made of polyester, which presents better resistance to UV degradation (Dial and Tobin 1994). Only the carabiner used to hang the swing (figure 1C) should be a specialized climbing device. The limitations of this swing are that it must be installed close to the climbing 
rope, and, therefore, does not allow a view of the tree from outside the canopy, the way it could be viewed from a crane. Also, it cannot be easily used when working with large or heavy data collecting instruments.

This swing was designed to observe birds in the canopy of a Chilean temperate rainforest (Díaz 2009). When tested, it allowed extremely comfortable fieldwork during each four-hour birdwatching session. This swing is perfectly suitable for observing any wildlife in the forest canopy, such as arboreal mammals or flower pollinators (Smith-Ramírez et al. 2005), as well as birds in their nests and birds as they move over the canopy from emergent trees (Loiselle 1988, Munn 1991), but its utility is not restricted to wildlife observations. It offers a suitable standpoint for wildlife photography, observation of raptors' nests in cliffs or it can simply be used to rest and contemplate the scenery when climbing a tree just for fun.

\section{ACKNOWLEDGEMENTS}

We thank A. M. Venegas and C. Tejo for support, A. Sepúlveda for technical assistance, and G. Criado and E. Díaz for figures. We are grateful to J. J. Armesto for comments that greatly improved the manuscript. Special thanks to $\mathrm{K}$. Velasquez and J. De La Calle for providing housing during fieldwork and access to their forested land. This paper is part of a study funded by Fondecyt grant 1050225, by the Canon National Parks Science Scholars Program, and by FONDAP-FONDECYT grant 1501-0001 to the Center for Advanced Studies in Ecology and Biodiversity. This is a contribution to the research program of LTSER network at Senda Darwin Biological Station, Ancud, Chiloé.

\section{REFERENCES}

Barker MG, SL Sutton. 1997. Low-tech methods for forest canopy access. Biotropica 29(2): 243-247.

Barker MG, MA Pinard. 2001. Forest canopy research: sampling problems, and some solutions. Plant ecology 153: 23-28.

Bates, M. 1944. Observations on the distribution of diurnal mosquitoes in a tropical forest. Ecology 25(2): 159-170.
Bouricius BA, E Stokes, BB Schultz. 2002. The canopy platform: an economical but limited access technique. In Mitchell AW, K Secoy, T Jackson eds. The global canopy handbook. Oxford, England. Global Canopy Programme. p. 29-32.

Dial R, SC Tobin. 1994. Description of arborist methods for forest canopy access and movement. Selbyana 15(2): 24-37.

Díaz IA. 2009. Linking composition, structure and functions of biodiversity: relationships among epiphytes, invertebrates and birds in the canopy of Chilean temperate rainforests. $\mathrm{Ph}$. D. dissertation. Gainesville, Florida, USA. University of Florida. 168 p.

Laman TG. 1995. Safety recommendations for climbing rain forest trees with "single rope technique". Biotropica 27(3): 406-409.

Loiselle BA. 1988. Bird abundance and seasonality in a Costa Rican lowland forest canopy. The Condor 90: 761-772.

Lowman MD, B Bouricius. 1995. The construction of platforms and bridges for forest canopy access. Selbyana 16(2): 179184.

Lowman MD, HB Rinker. 2004. Forest canopies, second edition. Burlington, USA. Elsevier Academic Press. 517 p.

Mitchell AW, K Secoy, T Jackson. 2002. The global canopy handbook. Oxford, England. Global Canopy Programme. $248 \mathrm{p}$.

Munn CA. 1991. Tropical canopy netting and shooting lines over tall trees. Journal of Field Ornithology 62(4): 454-463.

Munn CA, BA Loiselle. 1995. Canopy access techniques and their importance for the study of tropical forest canopy birds. In Lowman MD, NM Nadkarni eds. Forest canopies. San Diego, USA. Academic Press. p. 165-177.

Nadkarni NM. 1988. Use of a portable platform for observations of tropical forest canopy animals. Biotropica 20(4): 350351.

Nadkarni NM, TJ Matelson. 1989. Bird use of epiphyte resources in Neotropical trees. The Condor 91: 891-907.

Perry DR. 1978. A method of access into the crowns of emergent and canopy trees. Biotropica 10(2): 155-157.

Perry DR, J Williams. 1981. The tropical rain forest canopy: a method providing total access. Biotropica 13(4): 283-285.

Smith-Ramírez C, P Martinez, M Nuñez, C González, JJ Armesto. 2005. Diversity, Flower visitation frequency and generalism of pollinators in temperate rain forests of Chiloé Island, Chile. Botanical Journal of the Linnean Society 147: 399-416. 